\title{
2 方程式モデルによるトレンチ付開水路落差工流れの数值解析
}

\author{
Numerical Analysis of Flow of Open-channel with a Trench \\ by Two-Equation Turbulence Model
}

岡部 功*・中山 昭彦**

\section{Isao OKABE and Akihiko NAKAYAMA}

\author{
* 学生会員 神戸大学大学院自然科学研究科建設学専攻(广T657-8501 神戸市灘区六甲台町 1-1) \\ **正会員 Ph.D. 神戸大学教授 大学院自然科学研究科地球環境科学専攻(
}

\begin{abstract}
Complex flows over a drop with a trench in which supercritical and subcritical flow coexist, have been computed by a low Reynolds number $k-\omega$ turbulence model and the standard $k-\varepsilon$ model. The $k-\omega$ model predicts the free-surface shape, separation area and the turbulent kinetic energy and shear stress distributions in both test cases consistently well , while $\mathrm{k}-\varepsilon$ model fails to reproduce the case of supercritical flow over and past the trench. The calculation results imply that complex flow over the drop and trench cannot be represented properly by the method that relies on the wall function boundary condition.
\end{abstract}

Key word: two-equation turbulence model, free-surface, $k$ - $\omega$ model, trench

\section{1. はじめに}

近年の計算機の発達，また更なる発達の展望を見 ると，流体運動を予測するにあたって，数值解析の 担う所は益々大きくなっている. 乱流現象の数值解 析手法には直接シミュレーション (DNS) や Large Eddy Simulation など幾つかあるが，工学的には，計 算負荷の少ないことから，レイノルズ応力に乱流モ デルを適応した RANS 法が用いられている. RANS 法は他の乱流解析手法に比べ簡便であるが，それゆ えに精度や，適用範囲に制約がある. 今後，計算機 の発達に伴って計算手法に選択肢が広がる中で，ど の手法を用いるかを判断する材料として, RANS 法 の精度や再現吽, 可能性を知ることは少なからず意 味を持つ。

複雑な開水路乱流の代表として Fujita ${ }^{1)}$ は開水路 落差工流れを対象に画像計測を行い, 乱流量につい て詳しい実験結果を得ている，そこで本研究では， 実験と同様な水面変動を含む 2 次元開水路落差工流 れ（トレンチ流れ）を対象に, RANS 法の 2 方程式 モデルを用いて数値解析を行った. その結果を, Fujita $^{1}$ による実験と比較する事により，モデルの予 測精度, 適用範囲などを検証した. 数值計算に用い た 2 方程式モデルとして, 低レイノルズ数型 $\mathrm{k}-\omega$ モ

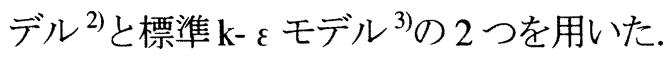

\section{2. 乱流モデル}

\section{1 基礎方程式と 2 方程式モデル}

ここでは本研究で用いた，低レイノルズ数型 $\mathrm{k}-\omega$ モ デルと標準 $\mathrm{k}-\varepsilon$ モデルの 2 つの 2 方程式モデルについ ての概要を記述する. 支配方程式であるレイノルズ平 均された連続の式と運動方程式は

$\frac{\partial U_{i}}{\partial x_{i}}$

$\frac{D U_{i}}{D t}=g_{i}-\frac{1}{\rho} \frac{\partial P}{\partial x_{i}}+\frac{\partial}{\partial x_{j}}\left(2 \vee S_{i j}-\overline{u_{i} u_{j}}\right)$

である. 計算は, 2 次元とし，ここで $x_{1}$ は流下方向， $x_{2}$ は鉛直上向き方向, $U_{i}, u_{i}$ は $x_{i}$ 方向の平均流速成分 と変動流速成分, $P$ は平均圧力, $\rho$ は流体密度, $\nu$ は 動粘性係数, $S i j=\left(\partial_{i} U_{j}+\partial_{j} U_{i}\right) / 2, g_{i}$ は重力加速度の $x_{i}$ 成分である. $-\overline{u_{i} u_{j}}$ はレイノルズ応力で, 本研究 では渦粘性モデルを用いて次式のように表す。

$-\overline{u_{i} u_{j}}=2 v_{t} S_{i j}-\frac{2}{3} k \delta_{i j}$

$v_{t}$ は渦動粘性係数, $k$ は乱流エネルギー， $\delta_{i j}$ はクロネ ッカーのデルタである. $v_{t}$ に関しては, k- $\varepsilon$ モデルで は Launder and Spalding ${ }^{3)} に よ り ，$

$v_{t}=C_{0} \frac{k^{2}}{\varepsilon}$

とおく. $\varepsilon$ はエネルギーの散逸率で, $C_{0}$ は係数. 本研 
究ではJones \& Spalding ${ }^{3)} に よ る$ 標準k- $\varepsilon$ モデルの值を 用いる. k- $\omega$ モデルでは Wilcox ${ }^{2)}$ の低レイノルズ数型 $\mathrm{k}-\omega$ モデルを用いた． $v_{t}$ の計算には $k$ と $\varepsilon /(\beta * k)$ で定 義される比エネルギ一の散冕率 $\omega$ を用いる. $k, \varepsilon, \omega$ はそれぞれの輸送方程式を解くことにより求められる.

\section{2 水面効果を考慮したモデル}

Nezu \& Rodi ${ }^{4)}$ によって, 開水路流では管路流に比べ, 渦動粘性係数が水路中央付近から水面近傍にかけて減 少する事が指摘されている. 2 方程式モデルの中の乱 流エネルギ一, 散逸率の值や, それらの輸送方程式に は水面に関寸る項は直接現れないので, 中山・横嶋 ${ }^{5)}$ は渦動粘性係数に水面効果を表すモデルを導入する方 法を提案している.

本研究では，水面に対して反射効果のみを考慮し， 渦動粘性係数を減衰させる関数を上述の低レイノルズ 数型 $\mathrm{k}-\omega$ モデルに適用し, 計算を行った. 具体的には 水面による $\nu_{t}$ の減少傾向を表すために減衰関数 $f_{s}$ を乗 じる. それらは次式ように表す。

$$
\begin{gathered}
v_{t}=\alpha^{*} f_{s} \frac{k}{\omega} \\
f_{s}=1-f_{r}
\end{gathered}
$$

$f_{r}=\exp \left(-C_{r} \frac{H-x_{2}}{L_{S}}\right)$

$L_{S}=C_{L} \frac{\sqrt{k_{s}}}{\omega_{s}}$

ここで添え字の $\mathrm{s}$ は水面での值を示寸. $H$ は水面の高 さ， $L_{s}$ は水面近傍での乱れ長さスケール， $C_{r}, C_{L}$ はモ デル定数で, $C_{r}=0.5, C_{L}=0.75$ を用いた.

\section{3. トレンチ付落差工流れ}

計算対象のトレンチ付落差工流れは Fujita ${ }^{1}$ によ り計測されている. 計測は長さ $7.5 \mathrm{~m}$, 幅 $0.3 \mathrm{~m}$, 高 さ $0.2 \mathrm{~m}$ の側壁、壁面ともガラス張りの循環式可変 勾配水路で行われた. 画像解析には定常状態の解析 にPTV 法, 非定常状態の解析に PIV 法を用いてい る. 図-1 に対象流れ場, 表-1 に実験の水理条件を示

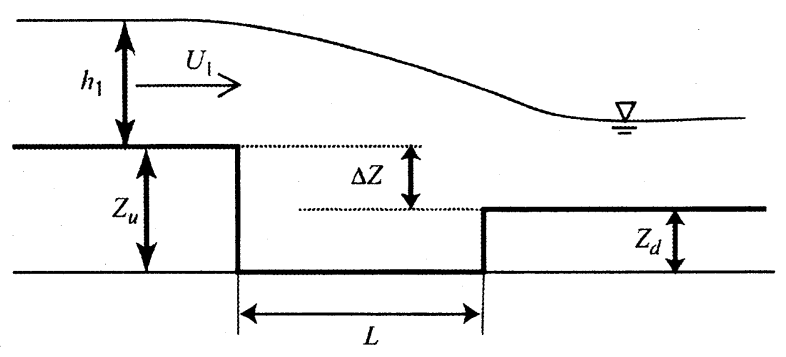

図-1 対象流れ場
す. 実験はトレンチの幅Lを変えて, 幾つかのケー スについて計測されている. 計算の水理条件を表-2 に示す．実験と計算の caseA, caseB, caseC はそれ ぞれ対応している.

実験は，トレンチ間のアスペクト比（As）を0の 状態から広くしていき, その都度の流況の変化を観 測している. 水面の状況は, アスペクト比 0 から 5. 5 までは, 計測区間内でほぼ変化せず滑らかに下流 部まで持続している.ただし下流側の水深はトレン 于規模の増大に伴って徐々に増加する結果を得て いる. アスペクト比 5.5 から 6.0 にかけてトレンチ 下流側の水面が急激な変化を示し， 6.5 を超えると トレンチ区間で砕波し振動跳水が開始される. 8 程 度をこえるとトレンチ区間に剥離流の再付着点が 現れ, 跳水はトレンチ内に定常的に留まるようにな ることが計測の上でわかっている.

実験と計算の水理条件を比較すると, $R e$ 数, $F r$ 数が一致していない. 実験では, 厳密に一定になっ ているわけでなく, 時々刻々, 多少の変動がある流 れを画像解析により計測し, $R e$ 数, $F r$ 数を算出し ている. そのため, 多少の誤差が考えられるが，そ れらの誤差は, 流れにはほとんど影響しないことが わかっている. この実験と計算の水理条件の差では, 結果に重大な影響を及ぼすことはない.

\begin{tabular}{|c|c|c|c|}
\hline & caseA & caseB & caseC \\
\hline 流量 : $Q \quad\left(\mathrm{~m}^{3} / \mathrm{s}\right)$ & \multicolumn{3}{|l|}{0.00227} \\
\hline 勾配 : I & \multicolumn{3}{|l|}{$1 / 500$} \\
\hline 流入水媣 : $h_{1}(\mathrm{~cm})$ & \multicolumn{3}{|l|}{1.95} \\
\hline 上流側トレンチ高 Zu $(\mathrm{cm})$ & \multicolumn{3}{|l|}{2.0} \\
\hline 下流側トレンチ高 : $Z_{d}(\mathrm{~cm})$ & \multicolumn{3}{|l|}{1.0} \\
\hline 流入平均流速: $U_{1}(\mathrm{~cm})$ & \multicolumn{3}{|l|}{38.9} \\
\hline 流入フルート数: $F r$ & \multicolumn{3}{|l|}{0.889} \\
\hline Reynolds 数: $R e$ & \multicolumn{3}{|l|}{7590} \\
\hline トレンチ間の長さ $: L \quad(\mathrm{~cm})$ & 0.0 & 3.5 & 6.0 \\
\hline アスペクト比：As $(L \Delta Z)$ & 0.0 & 3.5 & 6.0 \\
\hline
\end{tabular}

表-1＼cjkstart実験の水理条件

表-2 計算の水理条件

\begin{tabular}{|l|l|l|l|}
\hline & caseA & caseB & caseC \\
\hline 勾配 $: I$ & $1 / 500$ \\
\hline 上流側トレンチ高 $: Z_{l}$ & 1.0 \\
\hline 下流側トレンチ高 $: Z_{d}$ & 0.5 & \multicolumn{2}{|l|}{} \\
\hline Reynolds 数 $: R e ~\left(=U_{1} Z_{l} / \nu\right)$ & 8100 \\
\hline 流入フルード数 $: F r$ & 0.92 \\
\hline トレンチ間の長さ $: L$ & 0.0 & 1.75 & 3.0 \\
\hline アスペクト比 $: A s ~(U \Delta Z)$ & 0.0 & 3.5 & 6.0 \\
\hline
\end{tabular}




\section{4. 数值計算法}

数值計算は中瀬 ${ }^{6)}$ と同様に，等間隔直交座標のスタ ッガードメッシュ上で行われ，差分法を用いて基礎 方程式を離散化した. 対流項に UTOPIA スキーム, その他の空間微分項には中心差分を用いた. 時間進 行に, 2 次精度 Adams-Bashforth 法, 圧力解法に HSMAC 法を採用した. 図-2, 図-3 にそれぞれ、k$\varepsilon$ モデル， $\mathrm{k}-\omega$ モデルの計算に用いた計算格子を示 す. 流下方向を $x_{1}$, 鉛直方向を $x_{2}$ とすると, 図-2 の $\mathrm{k}-\varepsilon$ モデルの計算格子数は $\left(x_{1} \times x_{2}\right)=(178 \times 22)$ で, 図-3の k- $\omega$ モデルの計算格子数は $\left(x_{1} \times x_{2}\right)=$ $(178 \times 85)$ である.

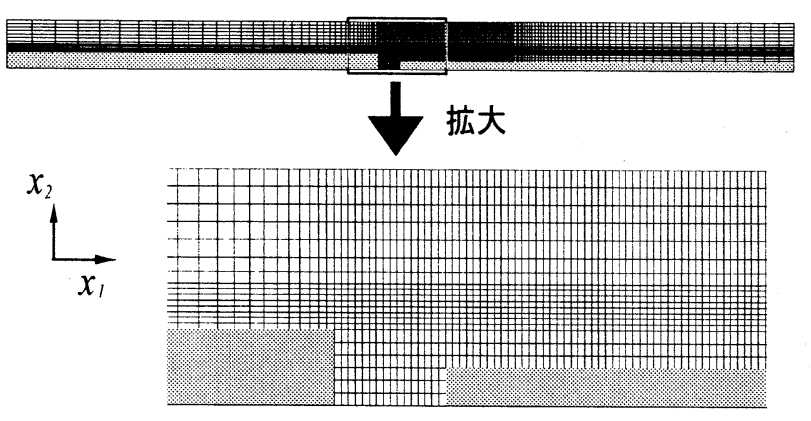

図-2ｋ- - モデルにおける計算格子

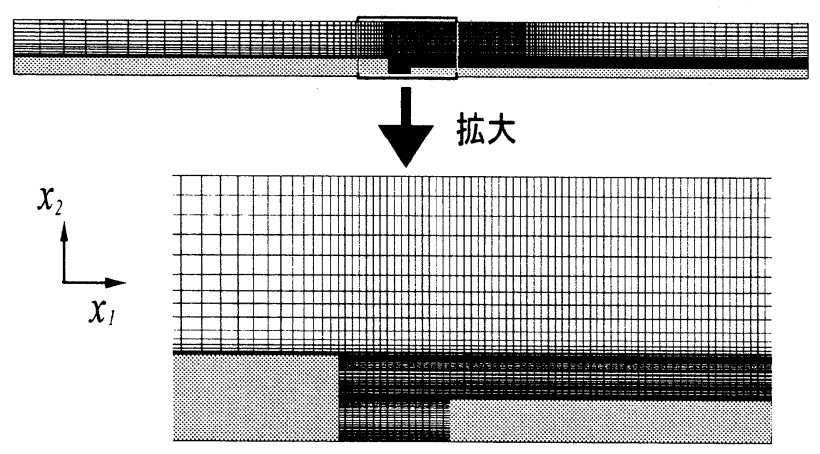

図-3 k-w・モデルにおけける訳算格子

移動境界を取り扱う数值計算手法として MAC 法や VOF 法, Level Set 法等の種々の計算法が提唱されてい る. 本研究で対象としているのは, 砕波や跳水が起こ らない流れであり，これらは水面位置の一価関数で定 義できる流れである. そのためアルゴリズムの簡単な オイラ一法を採用し, 自由表面の表現手段として, 高 さ関数法を用いた. 高さ関数法は次式で表される.

$$
\frac{\partial H}{\partial t}+U_{1 s} \frac{\partial H}{\partial x_{1}}=U_{2 s}
$$

ここで $H$ は水面の高さ， $U_{I s}, U_{2 s}$ はそれぞれ流下 方向の水面の速度, 鉛直方向の水面の速度である.
境界条件は, 自由水面上で圧力は大気圧と等しく し表面張力と粘性を考慮, 水面上でのせん断応力が ゼロとなるようにし， $k, \omega, \varepsilon$ にいては対称条 件とした。壁面における境界条件として，流速に粘

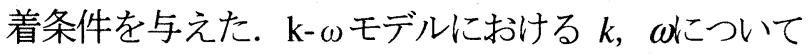
は次の条件を与えた。

$$
\begin{aligned}
& k=0 \\
& \omega=\frac{u_{\tau}^{2}}{v} S_{R}, \quad S_{R}= \begin{cases}\left(50 / k_{R}^{+}\right)^{2}, & k_{R}^{+}<25 \\
100 / k_{R}^{+}, & k_{R}^{+} \geq 25\end{cases}
\end{aligned}
$$

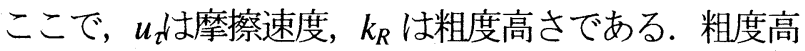
さは, 粗度レイノルズ数 $k_{R}^{+}$が 5 以下の滑面になるよう に設定した. k- $\varepsilon$ モデルの場合には, 固体壁面から第 1 番目の格子点で, 次の壁関数から与えた.

$$
\begin{gathered}
k=\frac{u_{\tau}{ }^{2}}{\sqrt{C_{\mu}}} \\
\varepsilon=\frac{u_{\tau}{ }^{3}}{\kappa n}
\end{gathered}
$$

ここで, 恃カルマン定数, $n$ は壁面からの距離である. 流入流速分布は, 流入流速分布は次式で表される, Spalding の三層モデル式によって与えた.

$$
\begin{array}{ll}
U_{1}^{+}=x_{2}^{+} & : 0 \leq x_{2}^{+}<5 \\
U_{1}^{+}=5.0 \ln x_{2}^{+}-3.05 & : 5 \leq x_{2}^{+}<30 \\
U_{1}^{+}=2.5 \ln x_{2}^{+}+5.5 & : 30 \leq x_{2}^{+}
\end{array}
$$

$U_{1}^{+}, x_{2}{ }^{+}$はそれぞれ, $U_{1}{ }^{+}=u / u_{\imath} x_{2}{ }^{+}=x_{2}$ utvで表され る無次元数である. 流出条件には， $u_{i}, k, \varepsilon, \omega$, 水面高さ $H$, につい, 流下方向に勾配ゼ口の対称 条件を与える自由流出条件とした. 初期条件として, 流れ場全体に流入速度分布を与え, 時間発展計算を 行った.

\section{5. 計算結果と考察}

図-4, 図-5, 図-6 はそれぞれ, caseA, caseB, caseC における実験と k- $\omega$ モデル, k- $\varepsilon$ モデルによる流速べ クトル分布の比較である. 図上には同時に, 剥離流線 と水面位置も示している. $U_{m}$ は流入の平均流速である.

それぞれのアスペクト比 0.0 と 3.5 の図-4, 図-5にお いて, k- $\omega$ モデルによる計算は実験とほぼ一致した結 果を得ている一方, k- $\varepsilon$ モデルは段落ち後間も無くに 剥離流が現れている. アスペクト比 6.0 の場合の図-6 では，実験はトレンチの段上がり部上端から剥離が現 れるのに対して, k- $\omega$ モデルは段上がり部上端から現 れず，剥離の位置は実験と比べて下流側で表れる. 図 -5, 図-6 を比べると k- $\varepsilon$ モデルでは, アスペクト比の 変化の影響が水面形, 剥離位置にほとんど現れてい 
(a)実験

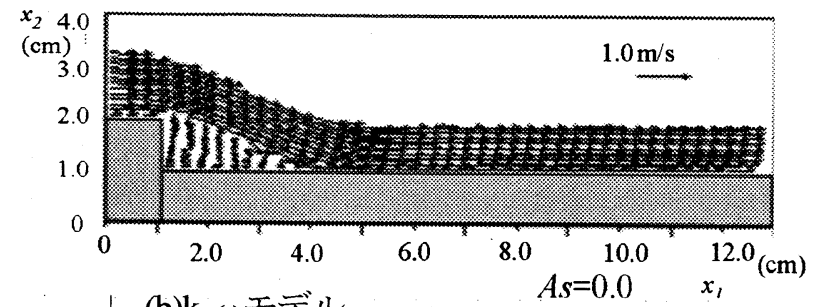

(b)k- $\mathrm{k}$ モデル

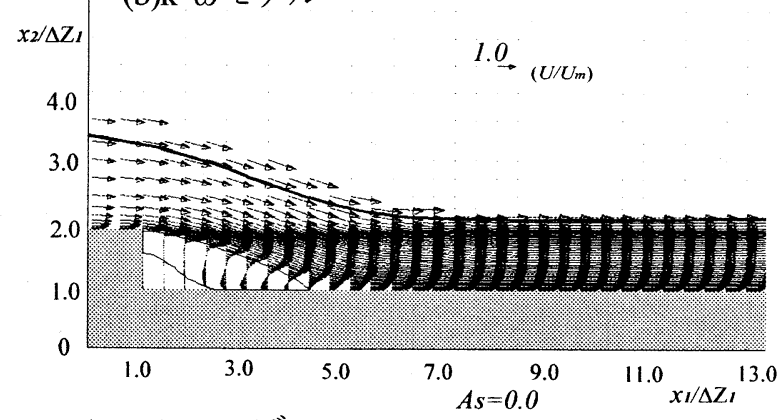

(c)k- $k$ モデル

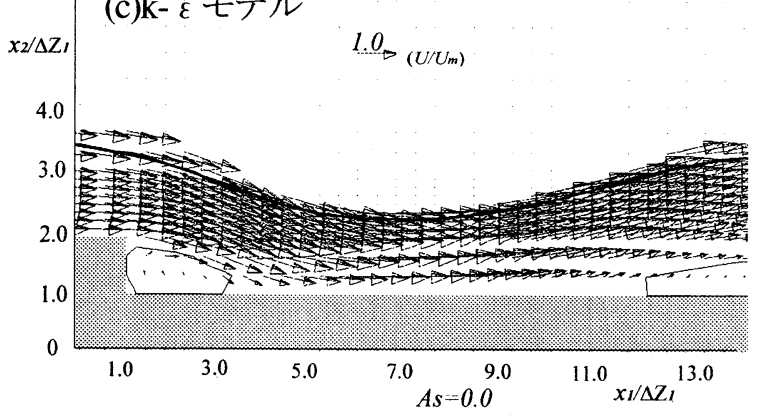

図-4 As=0.0の場合の流速ベクトル分布

ない.

図-7, 図-8 は caseB, caseC の実験と k- $\omega$ モデル, k- $\varepsilon$ モデルの乱流エネルギー分布の比較. 図-8, 図-10 は caseB， caseC の実験と k- $\omega$ モデル，k- $\varepsilon$ モデルのレイ ノルズ応力分布の比較である. 図-7, 図-8において, k- $\omega$ モデル, k- $\varepsilon$ モデルとも, トレンチ間内では実験 の傾向を概ね予測できている．実験の結果に着目する と，段上がり後に水面が隆起せずそのまま流れるケー スでは，乱流エネルギーのピークは壁面近くであり， 隆起するにつれてピークは壁面から離れている. k- $\omega$ モデルはその傾向を示しており，実験と図-7において は良く一致した水面形をしている. 一方， $\mathrm{k}-\varepsilon$ モデル ではその傾向を示していない. k- $\varepsilon$ モデルは境界条件 より，固体壁面から第 1 点目の乱流エネルギーと散逸 率を, 壁関数から求める. そのため壁面からある程度 離れている点が第 1 点目にあったならば, 本来大きく なるべき乱流エネルギーが，壁関数によって強制的に 与えられ，大きな值になりにくいことが考えられる. k- $\varepsilon$ モ゙゙ルがどのケースでも似た水面形になったのは, 壁面からの 1 点目がはなれていたため, 水面に何らか の影響を与えていた壁面近くの乱流エネルギーが再現 できなかったために起こった可能性がある，図-9，図 -10において, k- $\omega$ モデルは段上がり後において, 実験 結果とあまり一致が見られず，壁面近くに大きなレイ ノルズ応力が現れる傾向が見られた. (a)実験

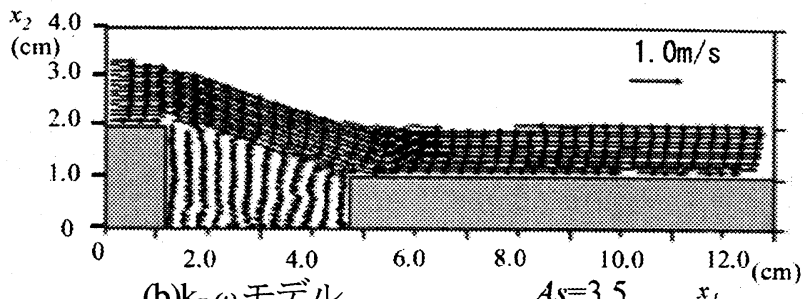

(b) $\mathrm{k}-\omega$ モデル
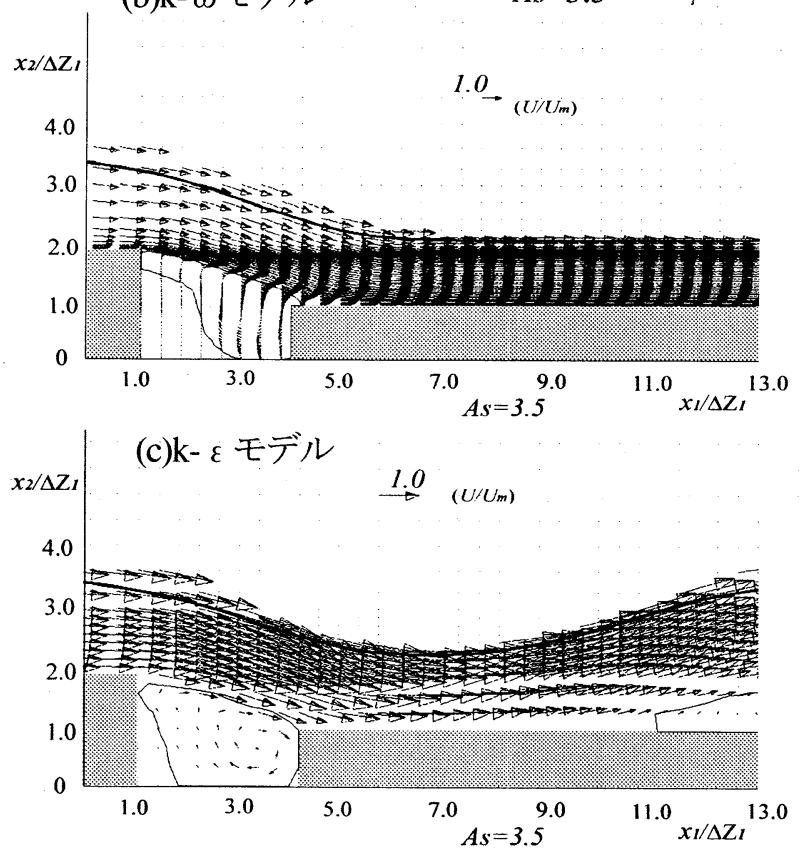

図-5 $\mathrm{As}=3.5$ の場合の流速ベクトル分布

(a) 実験
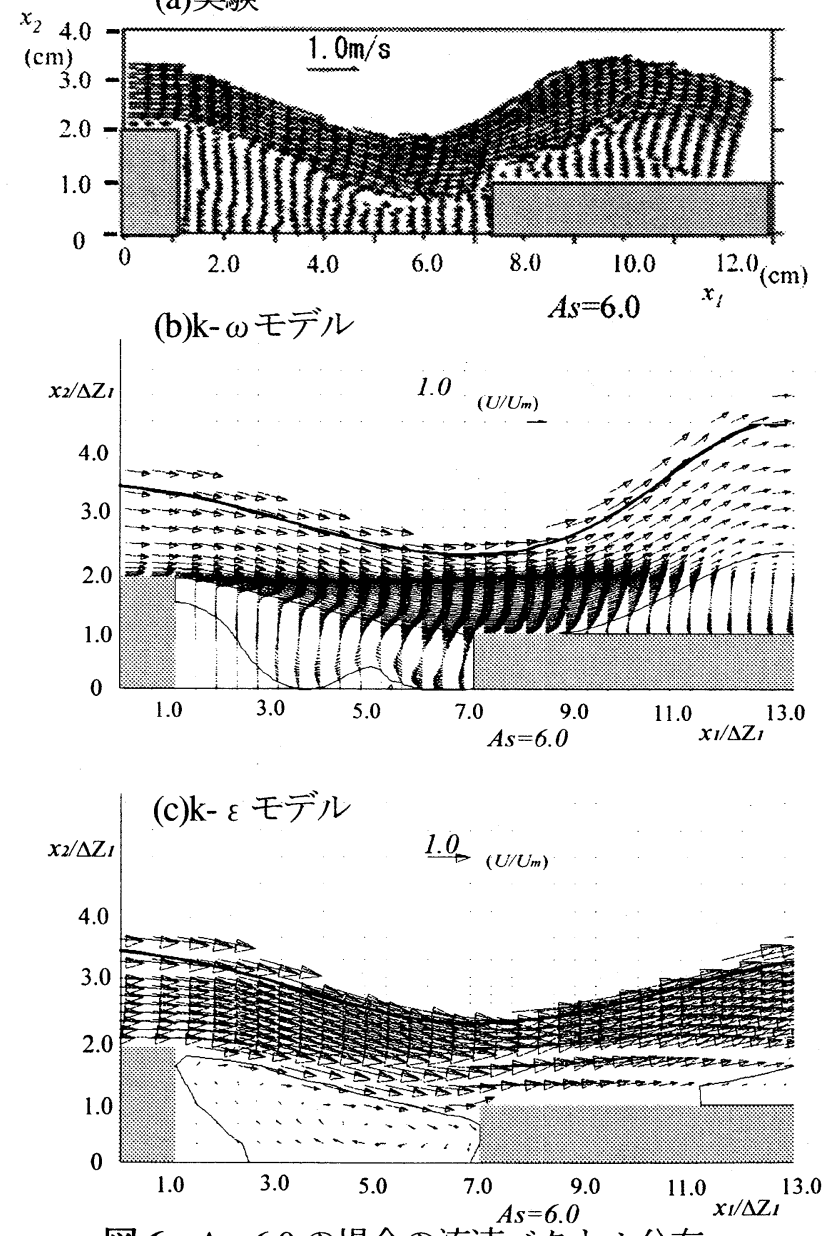

図-6 As=6.0 の場合の流速べクトル分布 


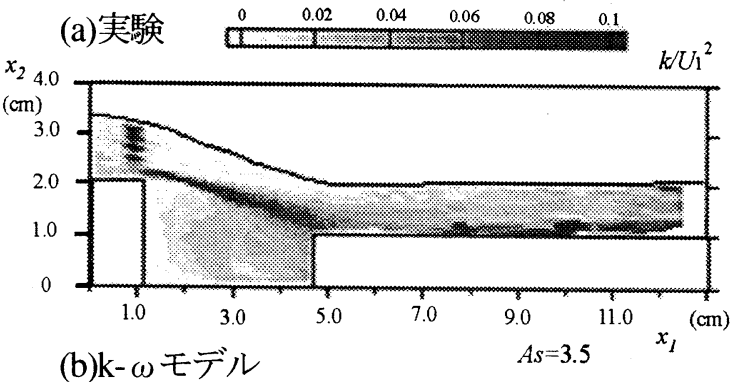

(b)k- $\omega$ モデル

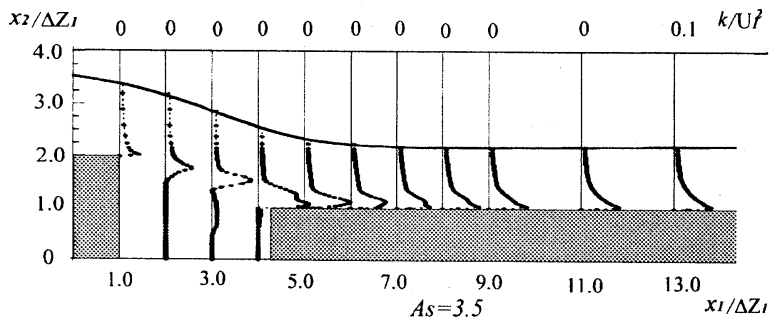

(c)k- $\varepsilon$ モデル

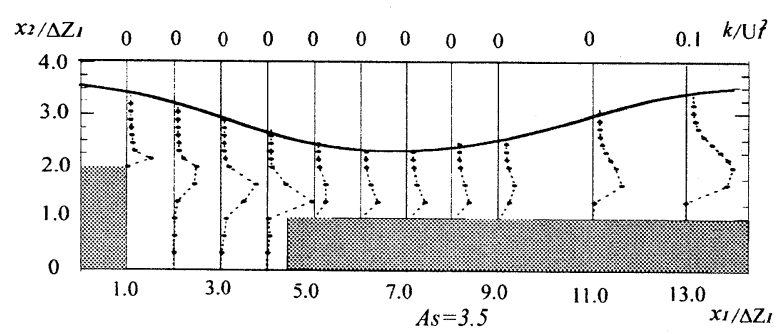

図-7 As=3.5 の場合の乱流エネルギ一分布

(a)実験 $\begin{array}{llllll}0 & 0.02 & 0.04 & 0.06 & 0.08 & 0.1\end{array}$

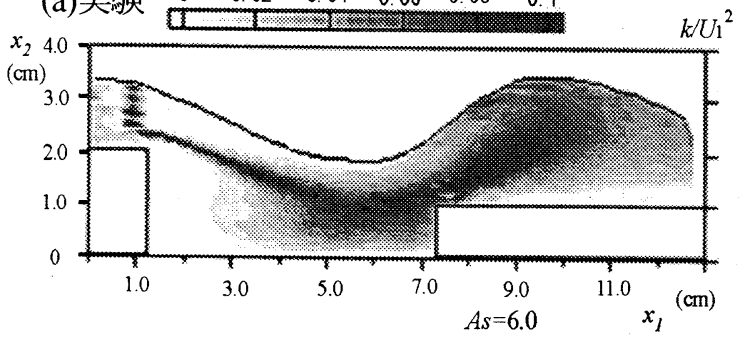

(b)k- $\omega$ モデル

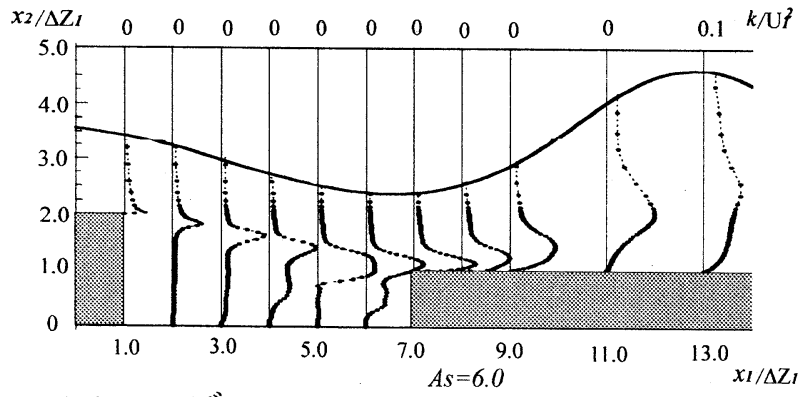

(c)k- $\varepsilon$ モデル

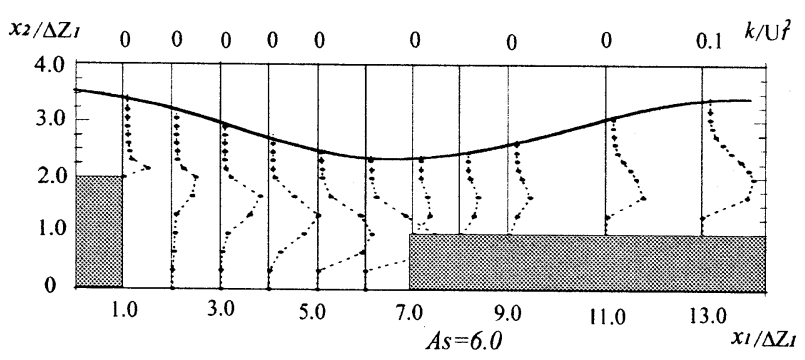

図-8 As=6.0 の場合の乱流エネルギー分布 (a) 実験 $\begin{array}{rrrrrrrr}-0.03 & -0.02 & -0.01 & 0 & 0.01 & 0.02 & 0.03 & 0.04\end{array}$

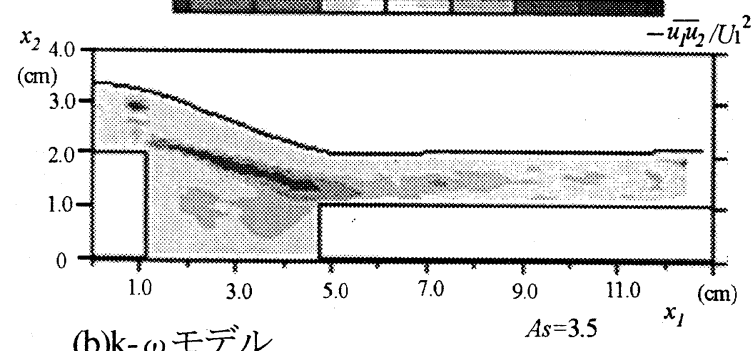

(b)k- $\omega$ モデル
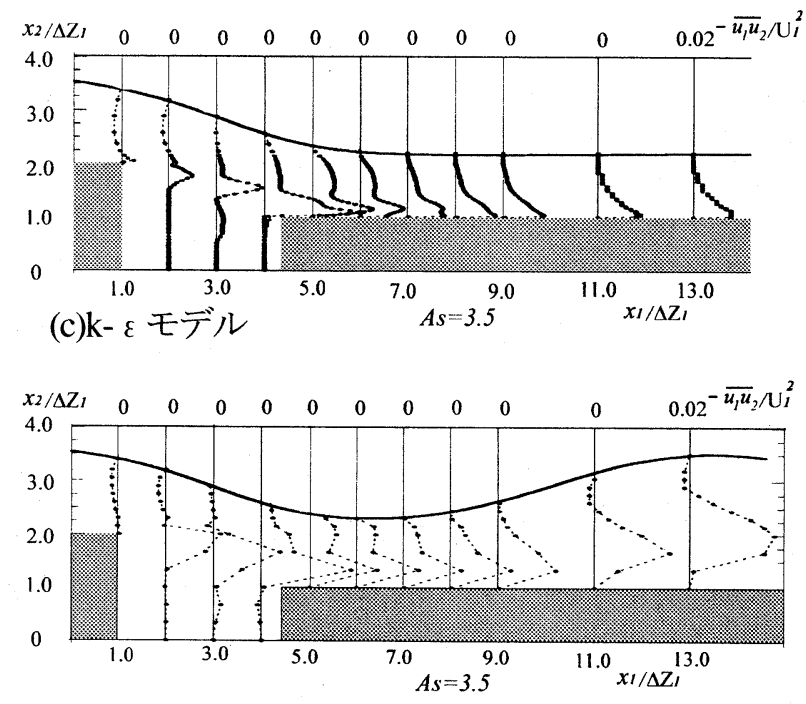

図-9 As=3.5 の場合のレイノルズ応力分布

(a) 実験

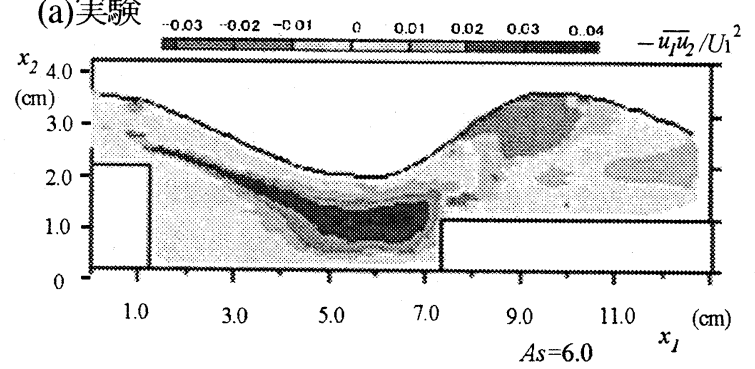

(b)k- $\omega$ モデル

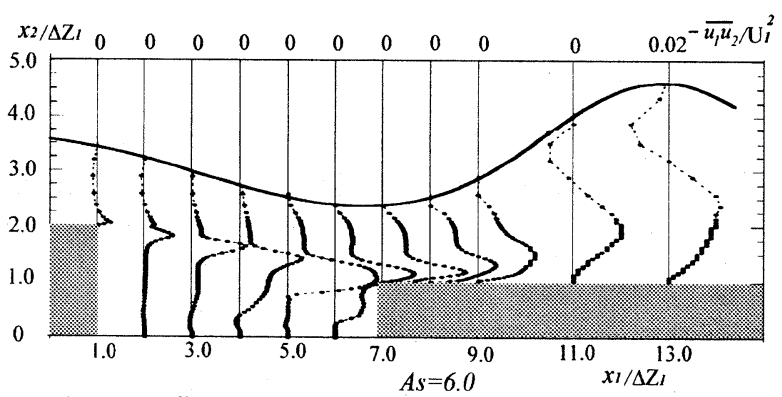

(c)k- $\varepsilon$ モデル

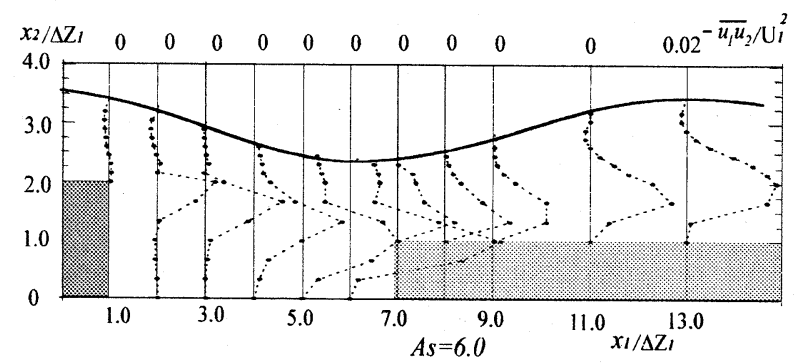

図-10 $A s=6.0$ の場合のレイノルズ応力分布 
図-11 は $x_{l}$ 方向座標に固定した, 幾つかの点におけ る水面高さの時間変化を表した図である. 図に示した 4 つの点は, 段上がり部の点, 水面が隆起し水面高さ がほぼピークになった時の点, そしてその前後の 2 点 である. 段上がり部の位置である $x_{I} / \Delta Z_{I}=6.0$ での值に 注目すると, $\mathrm{k}-\omega$ モデル, $\mathrm{k}-\varepsilon$ モデルともに $100(\mathrm{t})$ 前後 で定常状態になっていることが判断できる. k- $\varepsilon$ モデ ルは, 100(t)以後において示した 4 つの点でほぼ定常な 状態であった. k- $\omega$ モデルは, 段上がり部は 100(t)以後 において一定值に近い值を示したが，その他の点はあ る範囲内で時間変化があった. Fujita ${ }^{1)}$ 実験では周期 的に現れる振動跳水が測定されたが，図-11 は k- $\omega$ モ デルがその周期性のある非定常な流れを再現しうる可 能性を示唆している.

\section{6.結論}

砕波や跳水は起こらない範囲で，大きく水面形の変 化するトレンチ付の 2 次元開水路落差工流れに対して, 低レイノルズ数型 $k-\omega 2$ 方程式モデルと標準 $k-\varepsilon$ 型 2 方程式モデルを用いて, 数值解析を行った.

$\mathrm{k}-\omega$ モデルではトレンチの幅による水面形の変化や 乱流エネルギーの分布等, 実験の傾向を良く捉えられ た. k- $\varepsilon$ モデルの場合, トレンチ幅の変化に伴った水 面形の変化は現れなかった. $\mathrm{k}-\omega$ モデルは, ある程度 時間経過しても，k- $\varepsilon$ のようにほぼ完全な定常状態と ならなかった。これにより，実験に見られる周期的な 振動跳水のような非定常な流れを，k- $\omega$ モデルは表現 し得る可能性があることがわかった. 本研究で使用し た $\mathrm{k}$ - $\omega$ モデルは, トレンチ幅の少しの変化で大きく 流況が変わる複雑な構造を持つ流れに対して，ある程 度良好に傾向が捉えられた事から，今後，モデルの改 良により，より良い再現性が得られると考えられる。

\section{参考文献}

1) Fujita,I. : Particle Image Analysis of Open-channel Flow at a Backward Facing Step Having a Trench, Journal of Visualization, Vol.5, No.4, pp335-342, 2002.

2) Wilcox, D. C. : Turbulence Modeling for CFD,DCW Industries, Inc. La Canada, 1993.

3) Launder, B.E. and Spalding, D.B.: The numerical computation of turbulent flows, Computer Methods in Applied Mechanics and Engineering, Vol.103, pp.456-460, 1974.

4) Nezu, I. and Rodi, W.: Open-channel flow measurements with a laser Doppler anemometer, J. Hydraulic Engineering, ASCE, Vol.112, pp.335-355, 1986.

\section{(a)k- $\omega$ モデル}

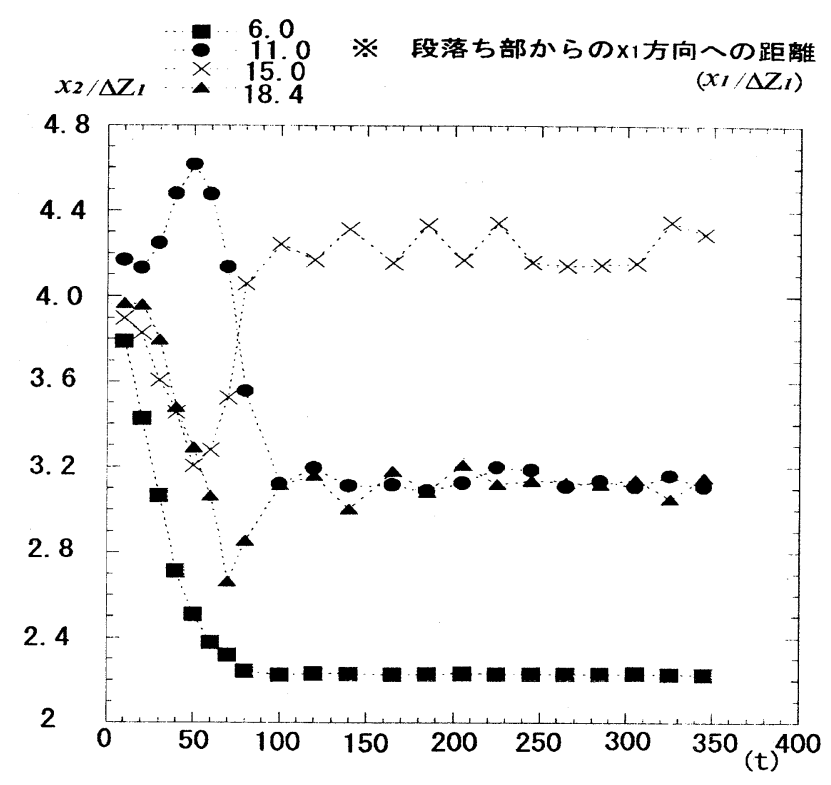

(b)k- $\varepsilon$ モデル
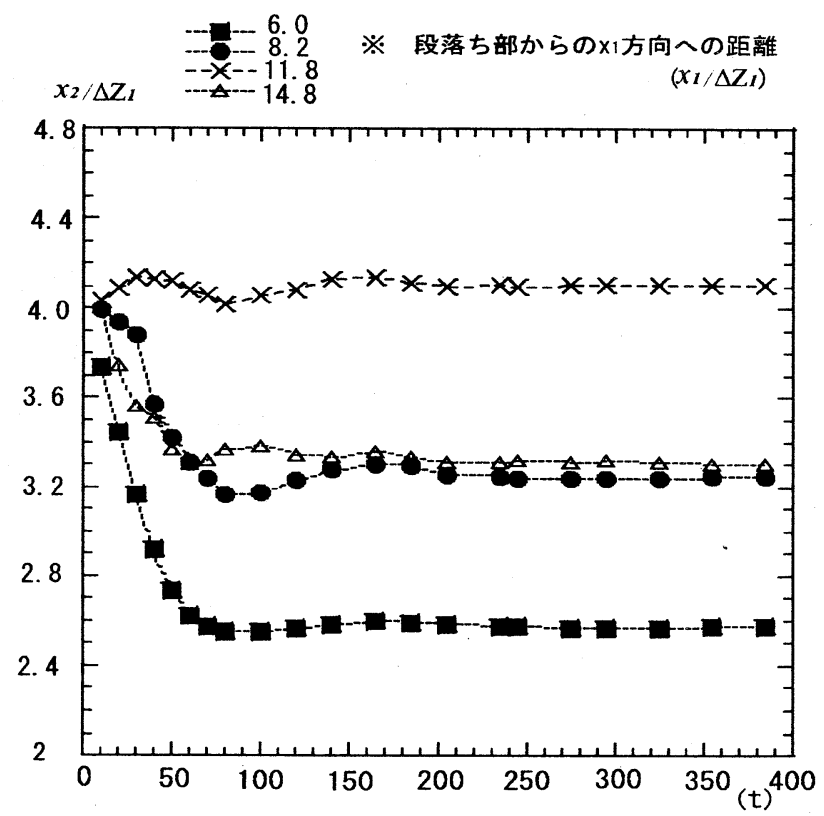

図-11 $x_{l}$ 方向に固定した 4 点の時間経過に伴う水面高さ

5）中山昭彦，横嶋哲 : 開水路流れ計算のための水面 変動を考慮した乱流モデル, 水工学論文集, 43, pp.389-394, 1999.

6) 中瀬幸典 : 乱流モデルを用いた非平衡開水路乱流 の数值計算法, 修士論文, 神戸大学大学院工学研 究科博士課程前期課程建設学専攻, 2002.

(2003 年 4 月 18 日受付) 